\title{
An Exo-D-galacturonanase of Butyrivibrio fibrisolvens from the Bovine Rumen
}

\author{
By KVETOSLAVA HEINRICHOVÁ, ${ }^{2}$ MARIA WOJCIECHOWICZ ${ }^{2}$ AND \\ A. ZIOLECKI ${ }^{2 *}$ \\ ${ }^{1}$ Institute of Chemistry, Slovak Academy of Sciences, 80933 Bratislava, Czechoslovakia \\ ${ }^{2}$ Institute of Animal Physiology and Nutrition, Polish Academy of Sciences, 05-110 Jabtonna, \\ Poland
}

(Received 13 September 1984; revised 18 January 1985)

\begin{abstract}
An intracellular pectinolytic enzyme was isolated from a cell extract of Butyrivibrio fibrisolvens and purified. The optimum $\mathrm{pH}$ for enzyme activity was $5 \cdot 6$. The enzyme preferentially degraded de-esterified substrates by hydrolysis of monosaccharide units from the non-reducing end; the only product of degradation was D-galacturonic acid. Values of $K_{\mathrm{m}}$ and $V_{\max }$ for oligo- and polygalacturonates indicated that the best substrate was digalacturonic acid; oligogalacturonates containing either a saturated or a $\Delta 4,5$-unsaturated non-reducing end were both degraded. The enzyme was classified as an exo-D-galacturonanase [poly(1,4- $\alpha$-D-galacturonide) galacturonohydrolase (EC 3.2.1.67)].
\end{abstract}

\section{INTRODUCTION}

Butyrivibrio fibrisolvens produces an extracellular pectinolytic enzyme which has been identified as an exopectate lyase (EC 4.2.2.9) (Wojciechowicz et al., 1982). As the final degradation product of this enzyme is a trigalacturonate that contains a $\Delta 4,5$-unsaturated nonreducing end, one might expect that another enzyme would be produced, to split the unsaturated trimer into monomers, probably inside the cell. The present paper describes the isolation and characterization of such an enzyme.

\section{METHODS}

Organism and growth. Butyrivibrio fibrisolvens strain 781 was isolated from the bovine rumen in this laboratory and has been used in our previous work (Wojciechowicz et al., 1982). It was grown in 10 litre batches in a medium containing $0.5 \%$ pectin as an energy source.

The cells were harvested by centrifugation using the KSB continuous flow system of the Sorvall SS-1 Superspeed centrifuge at $25000 \mathrm{~g}$ and a flow rate of $100 \mathrm{ml} \mathrm{min}^{-1}$, and washed twice with distilled water. The yield from 10 litres of culture was about $65 \mathrm{~g}$ wet weight of cells. The cells were suspended in $500 \mathrm{ml} 0.02 \mathrm{M}$-phosphate buffer, $\mathrm{pH} 7 \cdot 0$, and disrupted with an MSE $60 \mathrm{~W}$ ultrasonic disintegrator. The coarse debris and any residual cells were removed by centrifugation at $5500 \mathrm{~g}$ for $30 \mathrm{~min}$ at $4{ }^{\circ} \mathrm{C}$ and the crude extract was used for study.

Enzyme purification. The crude extract was treated with protamine sulphate to remove the nucleic acids (Rhodes et al., 1971). The extract was adjusted to $\mathrm{pH} 5.5$ with $1 \mathrm{M}$-acetic acid and a $2 \%(\mathrm{w} / \mathrm{v})$ protamine sulphate solution was added in a fine stream with vigorous agitation. The precipitate was removed by centrifugation at $5500 \mathrm{~g}$ for $30 \mathrm{~min}$ at $4{ }^{\circ} \mathrm{C}$. The supernatant was adjusted to $\mathrm{pH} 6 \cdot 0$, dialysed in $0.05 \mathrm{M}$-phosphate buffer, $\mathrm{pH} 7 \cdot 0$, and freezedried. The resulting powder $(5 \cdot 8 \mathrm{~g})$ was used as a crude enzyme preparation.

The crude preparation was further purified on a column of DEAE-Sephadex A-50 (fine) equilibrated with $0 \cdot 1 \mathrm{M}$ sodium acetate buffer, pH 6.0. The column was eluted with the same buffer and the course of the fractionation was followed by recording the absorbance at $280 \mathrm{~nm}$. Two protein peaks were obtained, one of which contained enzyme activity (Fig. 1). The active fractions were collected and desalted by gel filtration on Sephadex G-25 (medium) followed by chromatography on Sephadex G-75 equilibrated with 0.1 M-sodium acetate buffer, pH 5.2,

Abbreviation: TBA, thiobarbituric acid. 


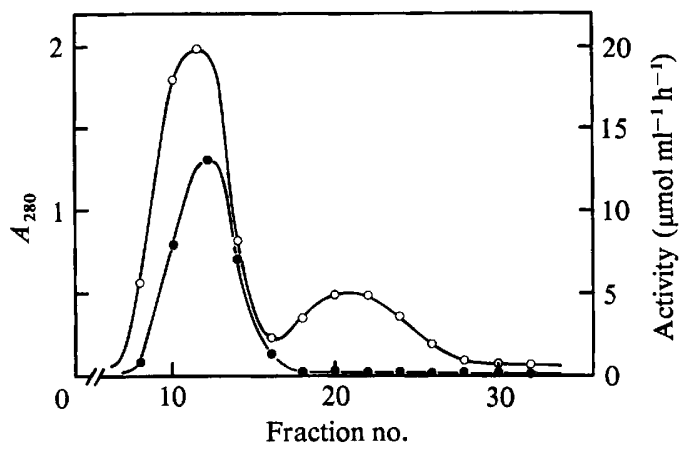

Fig. 1. Chromatography of the crude enzyme preparation on DEAE-Sephadex A-50. The column $(2.2 \times 52 \mathrm{~cm})$ was eluted with $0.1 \mathrm{M}$-sodium acetate buffer, $\mathrm{pH} 6.0$, at a flow rate of $20 \mathrm{ml} \mathrm{h}^{-1}$. The fraction volume was $10 \mathrm{ml}$. $\mathrm{O}, A_{280} ; O$, activity of D-galacturonanase.

containing $0 \cdot 1 \mathrm{M}$-sodium chloride. Only one coincident peak of activity and protein was obtained. The active fractions were pooled, desalted on Sephadex G-25 (medium) and freeze-dried. As compared to the crude preparation, a 60 -fold purification was obtained.

Substrates. Sodium pectate was prepared from citrus pectin (Genu Pectin, Københavns Pectinfabrik, Copenhagen, Denmark) by repeated alkaline de-esterification with $0 \cdot 1 \mathrm{M}-\mathrm{NaOH}$ for $2 \mathrm{~h}$ at $\mathrm{pH} 10$ and $22^{\circ} \mathrm{C}$. The de-esterified product was precipitated by adjusting the solution to $\mathrm{pH} 2.5$ with $\mathrm{HCl}$. The precipitate was neutralized with $\mathrm{NaOH}$ and dried. Sodium pectate contained $82.9 \%$ galacturonides and $10 \%$ neutral sugars. The molecular weight (estimated by viscosimetry) was 27000 .

Saturated oligogalacturonic acids (degree of polymerization, $n, 2$ to 9 ) were prepared by partial enzymic hydrolysis of sodium pectate followed by gel chromatography on Sephadex G-25 (fine) and desalting on Sephadex G-10 (Heinrichová, 1983). Di- and trigalacturonates containing $\Delta 4,5$-unsaturated non-reducing end groups were obtained as described earlier (Wojciechowicz, 1972).

Enzyme assays. The enzyme activity was assessed by spectrophotometric determination of the reducing groups using the Nelson-Somogyi reagent (Somogyi, 1952). Sodium pectate or pectin, $0 \cdot 5 \%(\mathrm{w} / \mathrm{v})$ in $0 \cdot 1 \mathrm{M}$-sodium acetate buffer, pH 5.6, or oligogalacturonates, $1 \mu \mathrm{mol}$ per $\mathrm{ml}$ of the same buffer, were used as substrates. The reaction mixture consisted of $0.5 \mathrm{ml}$ of the substrate solution and $0.5 \mathrm{ml}$ of the enzyme solution and was incubated for different times $(5,10,15,20,30$ and $60 \mathrm{~min})$ at $30^{\circ} \mathrm{C}$.

The initial velocity was obtained by a graphic extrapolation of experimental data describing the change of the reaction rate with time and was expressed as $\mu \mathrm{mol} \mathrm{s}^{-1} \mathrm{~g}^{-1}$. Only data from the linear range of reaction rates were used.

Enzyme activity was also determined by measuring the decrease in the viscosity of a sodium pectate solution. Enzyme solution $(2 \mathrm{ml})$ was incubated with $10 \mathrm{ml} 0.5 \%(\mathrm{w} / \mathrm{v})$ sodium pectate and $3.5 \mathrm{ml} 0.1 \mathrm{M}$-sodium acetate buffer, pH $5 \cdot 6$, at $30^{\circ} \mathrm{C}$. The viscosity of the incubation mixture was measured at hourly intervals for $24 \mathrm{~h}$ with an Ubbelohde viscometer. A simultaneous estimation of the reducing groups was also made and the percentage decrease of viscosity was related to the percentage increase in reducing groups.

Kinetic constants for digalacturonate were estimated using Lineweaver-Burk plots. Enzyme (0.5 mg ml-1) and substrate (in the concentration range 0.1 to $1.4 \mu \mathrm{mol} \mathrm{ml}^{-1}$ ) were incubated at $30^{\circ} \mathrm{C}$ for 30 and $60 \mathrm{~min}$. The $K_{\mathrm{m}}$ and $V_{\max }$ values were calculated by regression analysis of 18 experimental values (triplicate values for each of six different substrate concentrations).

The degradation products resulting from the action of the enzyme on sodium pectate and oligogalacturonates were estimated by TLC on Silufol silica gel sheets (Kavalier, Votice, Czechoslovakia) using a solvent system of butan-1-ol/formic acid/water ( $2: 3: 1$, by vol.) (Koller \& Neukom, 1964). To establish whether the enzyme attacks substrate from the reducing or non-reducing end, an unsaturated trimer was obtained by the action of $B$. fibrisolvens exopectate lyase on polygalacturonate; this substrate is unsaturated at the non-reducing end. The $\Delta 4,5-$ unsaturated trimer solution $(1 \mathrm{ml})$ was incubated with $1 \mathrm{ml}(0.02 \mathrm{~g})$ of enzyme solution in $0.1 \mathrm{M}$-sodium acetate

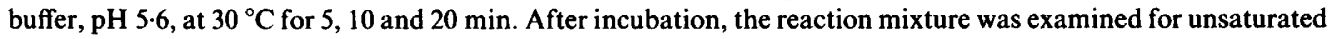
oligomers by measuring the UV-absorbance at $235 \mathrm{~nm}$, and by the thiobarbituric acid (TBA) test (Grossmann, 1968). Unsaturated oligomers and monomers react with TBA to produce a chromophore with a $\lambda_{\max }$ at $550 \mathrm{~nm}$. The degradation products were also identified by descending paper chromatography (Wojciechowicz et al., 1980). The paper chromatograms were evaluated using a Chromoscan 200 densitometer (Joyce-Loebl, Gateshead, UK) with aperture 0503 and filter 5042 . 


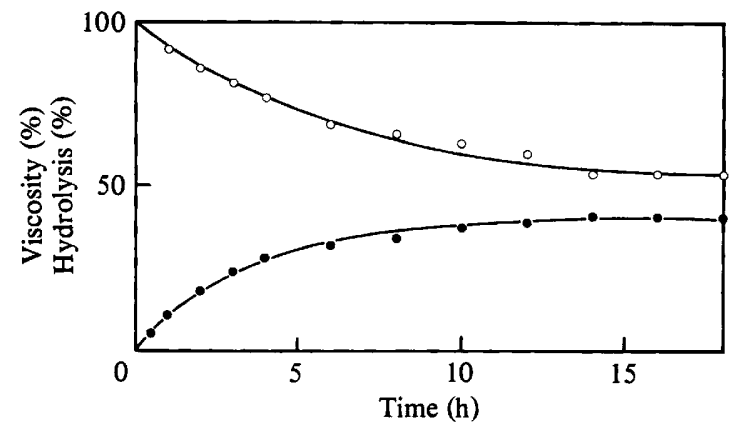

Fig. 2. Effect of enzyme action on $0.5 \%$ sodium pectate. The substrate, $10 \mathrm{ml} 0.5 \%$ sodium pectate and $3.5 \mathrm{ml}$ acetate buffer, pH 5.6, was incubated with $2 \mathrm{ml}$ enzyme solution at $30{ }^{\circ} \mathrm{C}$. $\mathrm{O}$, Percentage of initial viscosity;, increase of reducing groups expressed as percentage of glycoside bonds split.

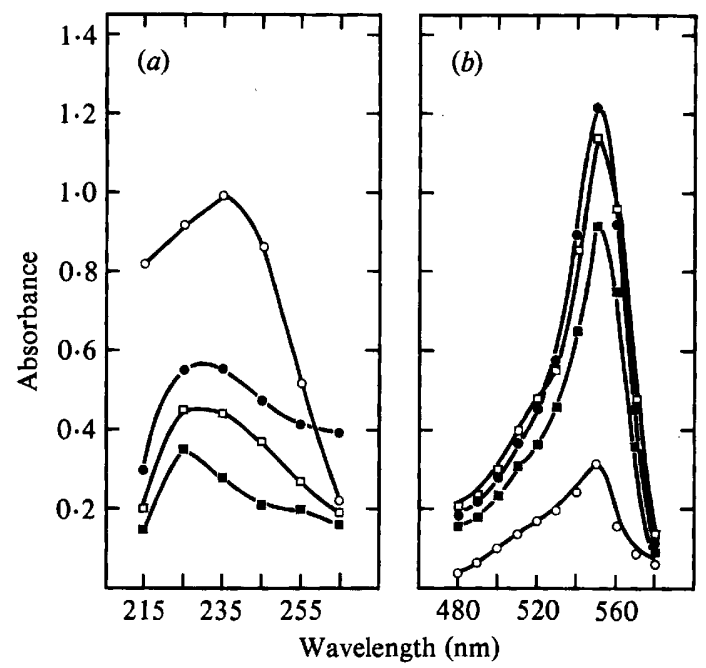

Fig. 3. Absorption spectra in the range 215 to $265 \mathrm{~nm}(a)$ and 480 to $580 \mathrm{~nm}$ (TBA test) (b) of the degradation products of unsaturated trigalacturonate incubated with enzyme preparation $\left(0 \cdot 2 \mathrm{mg} \mathrm{ml}^{-1}\right)$ in sodium acetate buffer, $\mathrm{pH} 5 \cdot 6$, at $30^{\circ} \mathrm{C}$ for $5 \mathrm{~min}(\bigcirc), 10 \mathrm{~min}(\square)$ or $20 \mathrm{~min}(\square)$. $\bigcirc$, Untreated trimer.

\section{RESULTS}

\section{Characterization and properties of the purified enzyme}

The specific activity of the purified enzyme towards sodium pectate was $1.70 \mu \mathrm{mol} \mathrm{s}^{-1} \mathrm{~g}^{-1}$, and towards digalacturonic acid $5.45 \mu \mathrm{mol} \mathrm{s}^{-1} \mathrm{~g}^{-1}$. The Michaelis constant for digalacturonic acid was $2.24 \pm 0.17 \times 10^{-4} \mathrm{~mol} \mathrm{l}^{-1}$ and $V_{\max }$ was $7.24 \pm 0.36 \mu \mathrm{mol} \mathrm{s}^{-1} \mathrm{~g}^{-1}$ (means $\pm \mathrm{SE}$ ).

The $\mathrm{pH}$ optimum of the purified enzyme was $5 \cdot 6$. The purified enzyme did not degrade sodium pectate completely; after $24 \mathrm{~h}$ incubation at $30{ }^{\circ} \mathrm{C}$ only $40.8 \%$ of the substrate was hydrolysed and the corresponding loss of viscosity was $46 \%$ (Fig. 2). The only product of degradation was D-galacturonic acid. These facts suggest an exo-enzyme. Negative results for the reactions with $o$-phenylenediamine and with TBA after paper chromatographic separation of the reaction mixture indicated that only saturated products were formed and therefore the enzyme was a hydrolase rather than a lyase.

After incubation of the unsaturated trimer with the enzyme, the paper chromatogram showed the presence of a saturated dimer and a saturated monomer when silver nitrate was used as the spray reagent. The unsaturated monomer gives a weak reaction with alkaline silver nitrate and 
Table 1. Rate of degradation of polymeric and oligomeric substrates by the purified enzyme of B. fibrisolvens

Substrate $(0.5 \%$ sodium pectate or pectin in $0.1 \mathrm{M}$-acetate buffer at pH 5.6 , or $1 \mu \mathrm{mol}$ of oligogalacturonates in $1 \mathrm{ml}$ acetate buffer) and enzyme solution, $0.5 \mathrm{ml}$ each, were incubated for 5,10 , $15,20,30$ and $60 \mathrm{~min}$ at $30^{\circ} \mathrm{C}$. Reducing values were estimated by the Nelson-Somogyi reagent.

$\begin{array}{lc}\text { Substrate } & \begin{array}{r}\text { Rate of degradation } \\ \left(\mu \mathrm{mol} \mathrm{s}{ }^{-1} \mathrm{~g}^{-1}\right)\end{array} \\ \text { Digalacturonate } & 5.45 \\ \text { Trigalacturonate } & 4.63 \\ \text { Tetragalacturonate } & 3.63 \\ \text { Pentagalacturonate } & 3.62 \\ \text { Hexagalacturonate } & 3.63 \\ \text { Sodium pectate } & 1.70\end{array}$

was not visualized by this method, but a chromatogram sprayed with $o$-phenylenediamine (Wojciechowicz et al., 1980) showed a spot corresponding to $\Delta 4,5$-unsaturated galacturonic acid. Moreover, the incubated reaction mixture did not absorb UV light at $235 \mathrm{~nm}$ (only unsaturated oligosaccharides absorb at this wavelength), but it did show a strongly positive reaction with TBA (Fig. 3) confirming the presence of the unsaturated monomer and absence of any other unsaturated product. This indicated that the enzyme split the unsaturated trimer to unsaturated monomer and saturated dimer and then the latter compound was degraded further to produce two saturated monomers. Similar results were obtained with the unsaturated tetramer obtained by the action of the pectate lyase of Streptococcus bovis (Wojciechowicz \& Ziolecki, 1984) on polygalacturonate. The tetramer was split to unsaturated monomer and saturated trimer, the latter being further degraded to saturated monomers. The results provide evidence that the enzyme attacks polygalacturonate from the non-reducing end.

\section{Initial rate of degradation of poly- and oligogalacturonates}

To estimate the initial rate of degradation $0.5 \mathrm{ml}(1 \mathrm{mg})$ of the purified enzyme in $0.1 \mathrm{M}$ sodium acetate buffer, $\mathrm{pH} 5.6$, was incubated with $0.5 \mathrm{ml}$ of $0.5 \%(\mathrm{w} / \mathrm{v})$ sodium pectate or pectin $\left(64.4 \%\right.$ esterified) at $30^{\circ} \mathrm{C}$ for 10,20 or $30 \mathrm{~min}$. In the case of oligomers, the incubation mixture contained $1 \mu \mathrm{mol}$ of the appropriate oligogalacturonate. The use of equimolar concentrations of the oligosaccharides eliminated differences in the degradation rate resulting from actual concentration of the terminal bonds subject to degradation. This enabled us to establish to what extent the degree of polymerization affected the degradation rate by the galacturonanase from B. fibrisolvens. The rate of degradation catalysed by the enzyme depended on the chain length of the substrates, digalacturonic acid being cleaved most rapidly (Table 1). In establishing the initial rate of degradation, only data from the linear range of reaction rates were used. The rates were linear for over $20 \mathrm{~min}$ with digalacturonate, over $30 \mathrm{~min}$ for trigalacturonate and over $60 \mathrm{~min}$ for longer chain lengths. The ratio of degradation rates of sodium pectate and digalacturonate was $1: 3 \cdot 2$. A similar ratio between the degradation rates of these two substrates was found for an exogalacturonanase isolated from the mycelium of the fungus Acrocylindrium (Kimura \& Mizishima, 1973).

Purified galacturonanase from $B$. fibrisolvens split oligogalacturonates of $n=4$ to 6 at the same rate, resembling in this respect the enzyme produced by Penicillium digitatum (Barash \& Angel, 1970). The faster hydrolysis of the trimer was probably due to the rapid removal of the primary degradation product, digalacturonic acid.

\section{DISCUSSION}

The results reported here indicate that the intracellular pectinolytic enzyme of $B$. fibrisolvens is a hydrolase. In view of its exo- mode of action and ability to split digalacturonate it has been classified as an exo-D-galacturonanase [poly(1,4- $\alpha \mathrm{D}$-galacturonide) galacturonohydrolase; EC 3.2.1.67]. 
The activity of most enzymes with a terminal mode of action depends on the chain length of the substrate. The optimal substrate for the exo-D-galacturonanase from $B$. fibrisolvens was digalacturonic acid. This disaccharide was also the preferred substrate for two exo-Dgalacturonanases of Aspergillus niger described by Mill $(1966 a, b)$ although the differences in the degradation rates between pectate and digalacturonate were in this case markedly greater $: 1: 85$ and $1: 11$, as compared to $1: 3 \cdot 2$ for $B$. fibrisolvens; the ratio reported by Hatanaka \& Ozawa (1969) for another $A$. niger exogalacturonanase was $1: 6 \cdot 3$. The degradation rate of oligogalacturonates by an extracellular exo-D-galacturonanase of $A$. niger was also studied by Heinrichová \& Rexová-Benková (1976). If equimolar concentrations of the substrates were used, the tetramer was degraded at the highest rate while the degradation rates of pectate and digalacturonate were similar. A similar activity towards oligomeric and polymeric substrates was found for another exo-D-galacturonanase of $A$. niger isolated from a commercial preparation (Heinrichová, 1981). Most pectinolytic rumen bacteria: Bacteroides ruminicola (Wojciechowicz, 1971), the treponemes (Wojciechowicz \& Ziołecki, 1979) and Lachnospira multiparus (Wojciechowicz et al., 1980) produce and release into the external environment a complex of pectinolytic enzymes consisting predominantly of polygalacturonate lyase, pectinesterase and very small amounts of galacturonanase. The demethylated pectin molecule is split rapidly and completely by the polygalacturonate lyase with an endo- mode of action, yielding unsaturated digalacturonate as the main end product of degradation. The latter is finally cleaved by the galacturonanase to monomers. The enzyme complex of $B$. fibrisolvens acting outside the cell differs from those of the other rumen bacteria in that it contains only pectinesterase and a polygalacturonate lyase with an exo- mode of action (Wojciechowicz et al., 1982), while the galacturonanase is cell associated. The lyase splits unsaturated trimer units from the reducing end of the demethylated pectin molecule. The trimer is then probably transported across the cell wall and cleaved by the galacturonanase inside the cell to one unsaturated and two saturated monomers.

Recently, the pectinolytic enzymes of Bacteroides thetaiotaomicron from the human colon have been described (McCarthy et al., 1985). This organism also produced a polygalacturonate lyase and a galacturonanase (the production of pectinesterase was not reported) but both enzymes were cell associated. The polygalacturonate lyase had a greater affinity for polygalacturonic acid than the galacturonanase ( $K_{\mathrm{m}} 40$ to 70 against 350 to $400 \mu \mathrm{g} \mathrm{ml}^{-1}$ ). This seems to suggest that not polygalacturonic acid but rather the oligomers, most probably the unsaturated dimer, end product of the action of the lyase on polygalacturonate, would be the preferentially degraded substrate for the Bacteroides thetaiotaomicron galacturonanase, a situation very similar to that with Butyrivibrio fibrisolvens.

\section{REFERENCES}

BARASH, I. \& ANGEL, E. (1970). Isolation and properties of an exopolygalacturonase produced by Penicillium digitatum during infection of lemon fruits. Israel Journal of Botany 19, 599-608.

GrossmanN, E. (1968). Zur Bildung pektischer und zellulolytischer Enzyme durch Phytophthora infestans de By. Phytopathologische Zeitschrift 62, 372-382.

HatanaKa, C. \& OzaWa, J. (1969). Enzymic degradation of pectic acid. XII. Structure of the deoxysugar produced from unsaturated oligo- and polygalacturonic acids by an exopolygalacturonase of Aspergillus niger. Journal of the Agricultural Chemical Society of Japan 43, 139-144.

Heinrichové, K. (1981). Purification and partial characterization of another exo-D-galacturonanase of Aspergillus niger. Biologia (Bratislava) 36, 197-202.

Heinrichová, K. (1983). Preparation of oligogalacturonic acids by enzymatic hydrolysis. Biologia (Bratislava) 38, 335-343.

heinRichová, K. \& Rexová-Benková, L. (1976).
Purification and characterization of an extracellular exo-D-galacturonanase of Aspergillus niger. Biochimica et biophysica acta 422, 349-356.

Kimura, H. \& Mizushima, S. (1973). Exopolygalacturonase from a strain of Acrocylindrium. Agricultural and Biological Chemistry 37, 2589-2593.

Koller, A. \& Neukom, H. (1964). Detection of oligogalacturonic acids by thin-layer chromatography. Biochimica et biophysica acta 83, 366-367.

MCCARThy, R. E., Kotarski, S. F. \& SAlyers, A. A. (1985). Location and characteristics of enzymes involved in the breakdown of polygalacturonic acid by Bacteroides thetaiotaomicron. Journal of Bacteriology 161, 493-499.

MILL, P. J. (1966a). The pectic enzymes of Aspergillus niger. A mercury-activated exopolygalacturonase. Biochemical Journal 99, 557-561.

MiLL, P. J. (1966b). The pectic enzymes of Aspergillus niger. A second exopolygalacturonase. Biochemical Journal 99, 562-565. 
Rhodes, C., Germershausen, J. \& Suskind, S. R. (1971). Neurospora crassa: preparative scale for biochemical studies. Methods in Enzymology 22, 8086.

Somogyi, M. (1952). Notes on sugar determination. Journal of Biological Chemistry 195, 19-23.

WoJCIECHOWICZ, M. (1971). Partial characterization of pectinolytic enzymes of Bacteroides ruminicola isolated from the rumen of a sheep. Acta microbiologica polonica, Ser. $A, 3$ (20), 45-56.

WoJciechowicz, M. (1972). Comparison of the action of Bacteroides ruminicola polygalacturonic acid lyase and pectinase on lower oligogalacturonides. Acta microbiologica polonica, Ser. A, 4 (21), 189-195.
WojCiechowicz, M. \& Ziolecki, A. (1979). Pectinolytic enzymes of large rumen treponemes. Applied and Environmental Microbiology 37, 136-142.

WoJCIECHOWICZ, M. \& ZIOLECKI, A. (1984). A note on the pectinolytic enzyme of Streptococcus bovis. Journal of Applied Bacteriology 56, 515-518.

WoJCIECHOWICZ, M., HeINRICHOVÁ, K. \& ZiOleCKI, A. (1980). A polygalacturonate lyase produced by Lachnospira multiparus, isolated from the bovine rumen. Journal of General Microbiology 117, 193-199. WoJCIECHOWICZ, M., HeINRICHOVÁ, K. \& ZIOLECKI, A. (1982). An exopectate lyase of Butyrivibrio fibrisolvens from the bovine rumen. Journal of General Microbiology 128, 2661-2665. 